One Corner of the SQuare 



\title{
One Corner
}

\author{
of the \\ SQUARE
}

\section{Essays on the Philosophy of Roger T. Ames}

EDITED BY

Ian M. Sullivan

AND

Joshua Mason

University of Hawai'i Press

Honolulu 
(C) 2021 University of Hawai'i Press

All rights reserved

Printed in the United States of America

$\begin{array}{llllllllllll}26 & 25 & 24 & 23 & 22 & 21 & 6 & 5 & 4 & 3 & 2 & 1\end{array}$

\section{Library of Congress Cataloging-in-Publication Data}

Names: Sullivan, Ian M., editor. I Mason, Joshua, editor.

Title: One corner of the square : essays on the philosophy of Roger T. Ames / edited by Ian M. Sullivan and Joshua Mason.

Description: Honolulu : University of Hawai'i Press, 2021. I Includes bibliographical references and index.

Identifiers: LCCN 2021003491 I ISBN 9780824884628 (cloth) I ISBN 9780824888213 (pdf) I ISBN 9780824888237 (epub) I ISBN 9780824888220 (kindle edition)

Subjects: LCSH: Philosophy, Chinese. I Philosophy, Comparative. I Ames, Roger T.,

Classification: LCC B5230 .O54 2021 I DDC 181/.11—dc23

LC record available at https://lccn.loc.gov/2021003491

University of Hawai'i Press books are printed on acid-free paper and meet the guidelines for permanence and durability of the Council on Library Resources. 
To the myriad teacher-student relationships

that made this volume possible 
